\title{
The Effect of Curcuma xamthorriza Roxb Extract on Hemozoin Pigmen Deposition in the Liver Tissue of BALB/C Mice Infected with Plasmodium berghei ANKA
}

\author{
Prawesty Diah Utami ${ }^{1}$, Irmawati M. Dikwan ${ }^{2}$, Ali Wibowo ${ }^{3}$ \\ 1 Parasitology, Faculty of Medicine, Hang Tuah University 60111, Indonesia \\ 2 Biology Medicine, Faculty of Medicine, Hang Tuah University 60111, Indonesia \\ ${ }^{3}$ Faculty of Medicine, Hang Tuah University 60111, Indonesia
}

Article history:

Submission December 2019

Revised April 2020

Accepted April 2020

*Corresponding author:

E-mail:

prawesty.diah@hangtuah.ac.id

\begin{abstract}
Hepatocellular damage is one of the histopathologic features of malaria infection. The presence of large amounts of hemozoin pigment in the liver is associated with hepatocellular damage. Curcuma xanthorriza Roxb / curcumin as an anti-inflammatory and natural antioxidant which has a hepatoprotector function. The purpose of these study was to determine the effect of curcuma rhizome (Curcuma xanthorrhiza Roxb) extract on hemozoin pigment in the liver tissue of BALB/C mice infected with Plasmodium berghei ANKA/ PbA. Method: using 25 groups of BALB/C mice, divided into 5 groups: negative control group; positive control group and 4 treatment groups infected with $\mathrm{PbA}$ with extract dose of $150 \mathrm{mg} / \mathrm{KgBW}, 100 \mathrm{mg} / \mathrm{KgBW}$, and $50 \mathrm{mg} / \mathrm{KgBW}$ for four days. On the fifth day the observation of liver tissue to determine deposition of hemozoin pigments by histopathological examination. Results: Statistical analysis showed that descriptively there was a decrease in hemozoin pigment in the liver tissue of mice $(150 \mathrm{mg} / \mathrm{KgBW}$ extract dose decreased the most hemozoin pigment compared to other doses), but there was no statistically significant difference between the treatment groups with positive controls ( $p>0.05)$. Conclusions: The administration of curcuma extract (Curcuma xanthorriza Roxb) has the potential to reduce the deposition of hemozoin pigment in liver tissue in BALB/C mice infected with Plasmodium berghei ANKA although statistically it is not significant.
\end{abstract}

Keywords: Malaria, Curcuma xanthorriza Roxb, Hemozoin Pigment, BALB/C mice, P. berghei ANKA and Live

\section{Introduction}

Malaria is an infectious disease caused by parasites from the Plasmodium genus which transmitted through the bite of female Anopheles mosquitoes [1]. The liver becomes an important organ that is directly involved in the malaria life cycle, which is in the exoeryrocytic phase. The liver becomes the first organ where sporozoites develop into merozoites, then merozoites enter the circulation to infect erythrocytes [2].

Hepatocellular damage is characterized by jaundice and liver dysfunction is associated with a high degree of parasitemia. The hemozoin $(\mathrm{Hz})$ pigment is released when infected erythrocytes rupture to release new merozoites into the circulation, in the intraerythrocytic cycle. Infected erythrocytes and Hz pigments will be phagocytes by various phagocytic cells, including liver cells, as evidenced by histopathological examination of liver tissue of malaria patients which shows the greatest deposition of $\mathrm{Hz}$ pigment compared to other organs [3]. Hz pigment deposition has also been shown to be associated with the severity of malaria infection in both humans and experimental ani-

\section{How to cite:}

Utami PD, Dikman IM, Wibowo A (2020) The effect of Curcuma xanthorriza Roxb extract on hemozoin pigment deposition in the liver tissue of BALB/C Mice infected with Plasmodium berghei ANKA. Indonesian Journal of Medical Science and Public Health 1 (1): 28 - 33. doi: 10.11594/ijmp.01.01.05 
mals. The pathogenesis of hepatocellular damage in malaria infection is poorly understood, in animals showing that the imbalance of proinflammatory and anti-inflammatory effects on the immunological response of malaria is the cause of hepatocellular damage [4].

The administration of artemisinin based combination/ ACT therapy against malaria was less effective and the absence of a malaria vaccine [5], were reasons to explore supporting therapies that accelerate and increase the effectiveness of malaria therapy.

Curcuma xanthorriza Roxb / curcumin contains active components flavonoids and curcumin have roles as anti-tumor, natural antioxidant which has a hepatoprotector function, immunomodulator, anti microba and antiplasmodia [6][7]. Previous studies have shown that the flavonoid content in Curcuma extract is around 21.31-33.81 mg QE / $\mathrm{g}$ [8] and also has $8.7-11.5 \%$ of curcumin[9]. Based on the information obtained about Curcuma xanthoriza as an antioxidant and antiparasite, a bioassay test was performed using experimental study to determine the effect of curcuma rhizome (Curcuma xanthorrhiza Roxb) extract on hemozoin pigment in the liver tissue of BALB/C mice infected with Plasmodium berghei ANKA.

\section{Material and Methods}

This research was an experimental study using the post-test only control group design. The study was conducted at the Institute of Tropical Disease, Airlangga University starting from the preparation stage, pre-treatment, treatment and dissection stage of experimental animals. Histopathological observation was carried out at the Pathology Anatomy Departement of Faculty Medicine, Airlangga University Surabaya. The study was approved by the ethics commission of the Faculty Medicine, University of Hang Tuah No. 01 / HC / EC / KEP UHT / XI / 2018.

\section{Preparation Mice Models}

The sample used was 25 male BALB /C mice ; 7-9 weeks old, average weight 25 grams. BALB / C mice infected with PbA were laboratory models that are mostly used to ex- plore malaria pathogenesis and pathophysiology, and to explain liver damage from ma-

laria infections [10]. Total sample was counted using Federer formula [11] based on Ihwah et al. research finding that increasing the number of replicates would reduce the error rate, is in line with Montgomery's assertion that replication is used to eliminate errors[11] :

$$
\begin{aligned}
& t(r-1) \geq 15 \\
& 5(r-1) \geq 15 \\
& 5 r-5 \geq 15 \\
& r \geq(15+5): 5 \\
& r \geq 5 \text { (minimum } 5 \text { mice/each group). } \\
& \text { t: total group research } \\
& r ; \text { number of replication }
\end{aligned}
$$

Samples were divided into 5 groups as follows:

1. G1: consisting of 5 mice without $\mathrm{PbA}$ infection and given CMC Na solution with Aquadest as negative control group.

2. G2: consisting of 5 mice infected with $\mathrm{PbA}$ and given $\mathrm{CMC} \mathrm{Na}$ solution with Aquadest.

3. G3: consisting of 5 mice infected with $\mathrm{PbA}$ and treated with Curcuma extract (Curcuma xanthorriza Roxb) at a dose of $150 \mathrm{mg} / \mathrm{KgBW} /$ day orally every day for 4 consecutive days:

4. G4: consisting of 5 mice infected with $\mathrm{PbA}$ and treated with Curcuma extract (Curcuma xanthorriza Roxb) at a dose of $100 \mathrm{mg} / \mathrm{KgBW} /$ day orally every day for 4 consecutive days.

5. G5: consisting of 5 mice infected with $\mathrm{PbA}$ and treated with Curcuma extract (Curcuma xanthorriza Roxb) at a dose of $50 \mathrm{mg} / \mathrm{KgBW}$ / day orally every day for 4 consecutive days.

The control group was given CMC Na solution with aquadest, because the treatment group (G3-G5) used CMC Na solvent for Curcuma extract to separate and dissolve the oil to prevent clots [12].

Previous studies conducted by Reddy et al. (2005) using mice that were inoculated with $\mathrm{PbA}$ at a dose of $100 \mathrm{mg} / \mathrm{KgBB}$, showed that curcumin could reduce blood parasitemia levels by $80-90 \%$. Therefore, these study used a 
dose of $150 \mathrm{mg} / \mathrm{KgBB}$ of mice / day, $100 \mathrm{mg}$ / $\mathrm{KgBB}$ of mice / day, and $50 \mathrm{mg} / \mathrm{KgBB}$ of mice / day [13].

Adaptation to the environment was carried out for 7 days in all groups of mice and maintained their condition, food and drink. Mice are placed in a plastic tub measuring $30 \times 20 \mathrm{~cm}$ and given husks.

\section{Plasmodium berghei ANKA Innoculation Process}

The blood of donor mice that had been calculated as a parasitemia percentage reached $\geq 20 \%$ and diluted with PBS, were taken as much as $200 \mu$ to be intraperitoneally infected to all groups of experimental mice. Each mice were infected with $1 \times 10^{6} \mathrm{PbA}$ infected erythrocytes on day 0 . Mice that have been infected are marked and put into a cage according to the treatment group. Then the mice were left until the parasite growth in all experimental animals within \pm 2 days. If all tested animals have proven to have positive parasitic growth, then all groups of experimental animals are ready to be given treatment. Observation of parasitemia level was made serially from day 1 to the last day of the study (day 5) $[14,15]$.

\section{Curcuma xanthorriza Roxb rhizome extract}

Curcuma rhizome (Curcuma xanthorriza Roxb) was obtained from the traditional market of Bangkalan of Madura island. The process of identifying rhizome curcuma to determine its species was carried out at the pharmaceutical laboratory of Widya Mandala University.

Preparation of the extraction process begins with the stages of cutting the rhizome into small pieces and dried in the sun. After drying, curcuma rhizome will be ground using a grinding tool with a hole diameter of $0.75 \mathrm{~mm}$.

Extraction process of Curcuma xanthorriza Roxb rhizome was done using maceration technique. A total of $5 \mathrm{~kg}$ of fresh curcuma rhizome, macerated with $96 \%$ ethanol as much as 1 liter to get a $500 \mathrm{mg}$ extract of curcuma rhizome. Soaking was done for 24 hours while stirring occasionally. The resulting extract was filtered with a Buchner funnel to obtain the filtrate. The residue was remastered 4 times. The extract obtained was concentrated with a rotary evaporator until a thick extract was obtained. The extract was stored at room temperature or heated to a low temperature $\pm 30^{\circ} \mathrm{C}$ to evaporate the remaining ethanol until a dry paste was formed [16][17]. The preparation of Curcuma xanthorriza Roxb solution was carried out by mixing Curcuma xanthorriza Roxb rhizome extract with distilled water and $\mathrm{CMC}-\mathrm{Na}$ solution as a solvent to be given to the treatment group every day for 4 days continuously using sonde.

\section{Liver Tissue Histopathology Examination}

On the 5th day the termination was carried out on mice using ether to take liver tissue. Liver tissue is stored in sterile tubes that have been given formalin $10 \%$ with a ratio between tissue and formalin liquid is 1: 10 [18].

Liver histopathological examination was done by microscopic examination using a binocular microscope. Observation of hemozoin pigment deposition was done by semi-quantitative scoring: (1) score 0 , if there is no deposition of $\mathrm{Hz}$ (2) score 1, if there is mild deposition of $\mathrm{Hz}(3)$ score 2, if there is moderate deposition of $\mathrm{Hz}(4)$ score 3, if there is severe deposition of $\mathrm{Hz}$ [19].

\section{Statistical Analysis}

Data analysis uses the One Way Anova comparison test if the data is normally distributed and homogeneous, but the results of these study showed that the data were not normally distributed so that the Kruskal Wallis and Mann Whitney tests are used. The significance level of $\alpha$ used is $5 \%$ or 0.05 means that in 100 tests there will be 5 incorrect tests.

\section{Results and Discussion}

Descriptive and statistical analysis results of hemozoin levels observation can be seen in Table 1. It was found that the highest hemozoin pigment value was based on that in group (G5) which was 2.6, whereas in group (G1/ negative control) the mean value of hemozoin pigment was the lowest.

Table 1. Sample Characteristic \& Kruskal Wallis Test 
PD Utami, IM Dikwan, A Wibowo, 2020 / The effect of Curcuma xanthorriza Roxb extract on hemozoin pigment deposition

\begin{tabular}{lccccc}
\hline \multicolumn{1}{c}{ Characteristic } & G1 & G2 & G3 & G4 & G5 \\
\hline $\mathrm{N}$ & 5 & 5 & 5 & 5 & 5 \\
Hemozoin Deposition Mean Score & 0 & 2 & $\begin{array}{c}1.4 \\
\boldsymbol{p = 0 . 0 0 2 *}\end{array}$ & 1.8 & 2.6 \\
Kruskall Wallis test & & & & \\
\hline
\end{tabular}

*: $p$-value $<0.05$ (Significance)

Table 2. Post Hoc Comparison Between Group

\begin{tabular}{lcccc}
\hline $\begin{array}{c}\text { Comparison Between } \\
\text { Group }\end{array}$ & N & $\begin{array}{c}\text { Hemozoin Deposition } \\
\text { Mean }\end{array}$ & $\begin{array}{c}\text { Hemozoin Deposition } \\
\text { Mean }\end{array}$ & p-Value \\
\hline G1 vs G2 & 5 & 0 & 2 & $\mathbf{0 . 0 0 5}^{*}$ \\
G1 vs G3 & 5 & 0 & 1.4 & $\mathbf{0 . 0 0 5}^{*}$ \\
G1 vs G4 & 5 & 0 & 1.8 & $\mathbf{0 . 0 0 4}^{*}$ \\
G1 vs G5 & 5 & 0 & 2.6 & $\mathbf{0 . 0 0 5}^{*}$ \\
G2 vs G3 & 5 & 2 & 1.4 & 0.166 \\
G2 vs G4 & 5 & 2 & 1.8 & 0.606 \\
G2 vs G5 & 5 & 2 & 2.6 & 0.166 \\
G3 vs G4 & 5 & 1.4 & 1.8 & 0.221 \\
G3 vs G5 & 5 & 1.4 & 2.6 & $\mathbf{0 . 0 2 0}^{*}$ \\
G4 vs G5 & 5 & 1.8 & 2.6 & $\mathbf{0 . 0 4 2}^{*}$ \\
\hline
\end{tabular}

*: $\boldsymbol{p}$-value $<0.05$ (Significance)

Based on descriptive and statistical analysis in Table 2. showed a significant difference about $\mathrm{Hz}$ levels of liver tissue between the negative control group (G1) and the other treat-

ment groups (G2-G5). The presence of hemozoin pigment deposition indicates the presence of a Plasmodium infection. In G1 hemozoin pigment was not found because it had not been inoculated with $P b A$ [20].

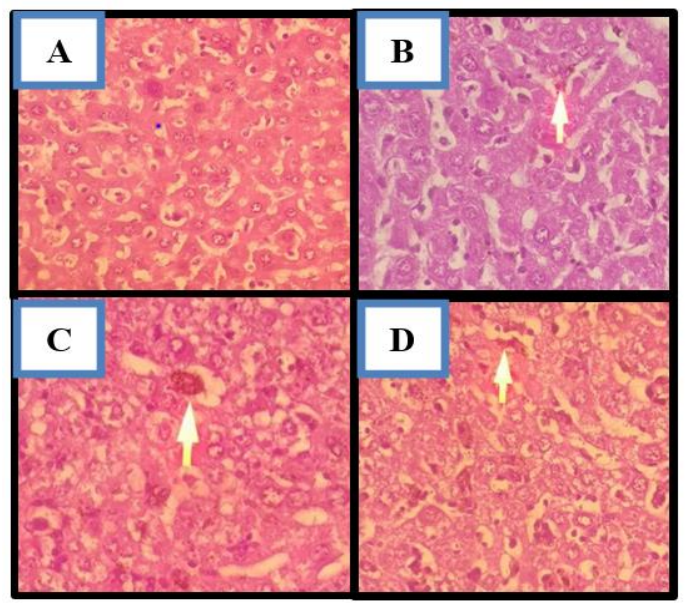

Figure 1. Hemozoin deposition on liver tissue

Picture of $\mathrm{Hz}$ deposition on liver tissue (A) Normal Tissue (B) Mild Deposition Hz (C) Moderate Deposition Hz (D) Severe Deposition Hz.

There was a difference on deposition of $\mathrm{Hz}$ between G2 (positive control) with G3 and G4, on G2 group showed that $\mathrm{Hz}$ deposition was higher than G3 and G4, but statistical analysis showed that there was no a significant difference. Reduction on pigment $\mathrm{Hz}$ deposition was due to the effect of the administration of curcuma extract, curcuma contains active substances which function to reduce the level of parasitemia, so that it will reduce the production of pigment hz. In the previous study describe that curcumin can inhibit beta hematin 
formation, which is the constituent of $\mathrm{Hz}$ pigment. Inhibition of the production of $\mathrm{Hz}$ pigment causes heme accumulation in cells. Heme was very toxic to cells, so it can cause oxidative stress which induces parasite cell death [21].

On the other hand, flavonoids has a strong antioxidant ability because in their structure, there are more than one phenol group and also has a conjugated double bond, where this structure was needed in binding free radicals. The ability to bind free radicals indicates that in addition to being used as an antioxidant, flavonoids can used as an anti-inflammatory [22].

$\mathrm{Hz}$ deposition on G5 is significantly higher than G3 and G4, but there was no a significant difference between G5 and G2, although $\mathrm{Hz}$ deposition on G5 was higher than G2. In the results of group 5 (G5) data, higher hemozoin pigment deposition results compared to positive control because it may be influenced by several factors: (1). Lack of dosage as single or main therapy(2). Variation of immune factor differences on mice are still unknown and therapeutic dose conversion with mice body weight is less suitable, (3). Flavonoids have the ability to damage cell walls that cause cell death so as to accelerate the deposition of Hz pigments [22]. So that in group 5 (G5) the level of parasitemia may be decreased by anti-malaria effects, but this effect does not significantly affect mechanism for cleaning $\mathrm{Hz}$ pigment deposition in the liver tissue of infected mice.

\section{Conclusion and Recommendation}

Based on the study results, it can be concluded that the administration of curcuma extract has potential effect to reduce of hemozoin pigment deposition on liver tissue of BALB/C mice inoculated with Plasmodium berghei ANKA, although the decrease was not significant compared to positive control group. In this study only carried out in 3 types of doses, further research needs to be done to determine the right dose of Curcuma xanthorriza Roxb extract to reduce parasitemia level but on the other hand can prevent deposition of hemozoin in liver tissue significantly.

\section{Acknowledgment}

This research was held with financial support from Faculty Medicine of the Hang Tuah University and the support of Institute Tropical Disease of Airlangga University, and Pathology Anatomy Department of the Faculty Medicine Airlangga University.

\section{References}

1. The Ministry of Health Republic of Indonesia (2015) National Malaria Control Program Strategic Plan 2015-2019.

2. Soulard V, Bosson-Vanga H, Lorthiois A, Roucher C, Franetich JF, Zanghi G, Bordessoulles M, Tefit M, Thellier M, Morosan S et al. (2015) Plasmodium falciparum full life cycle and Plasmodium ovale liver stages in humanized mice. Nat. Commun 6: 1-9.

3. Deroost K, Lays N, Pham TT, Baci D, Van Den Eynde K, Komuta M, Prato M, Roskams T, Schwarzer E, Opdenakker G, et al. (2014) Hemozoin induces hepatic inflammation in mice and is differentially associated with liver pathology depending on the Plasmodium strain. PLoS One 9: 1-23.

4. Jaijyan DK, Singh H (2014) Malaria Liver Stage Parasites Strategies for Immune Evasion and Host Modulation: Implication for Vaccine Design. Austin J. Vaccines Immunother 1: 1-5.

5. WHO Update on artemisinin resistance - April 2012 (2012) World Heal. Organ. 1-10.

6. Haddad M, Sauvain M, Deharo E (2011) Curcuma as a parasiticidal agent: A review. Planta Med. 77: 672-678.

7. Lwin KM, Mon HM, Myint KH (2017) Evaluation of the antimalarial activity of Curcuma longa Linn ., singly and in combination with Eupatorium odoratum Linn . J. Ayurvedic Herb. Med. 3: 11-14.

8. Khumaida N, Syukur M, Bintang M, Nurcholis W (2019) Phenolic and flavonoid content in ethanol extract and agromorphological diversity of Curcuma aeruginosa accessions growing in west java, Indonesia. Biodiversitas 20: 656-663.

9. Cahyono B, Ariani J, Failasufa H, Suzery M, Susanti S, Hadiyanto H (2019) Extraction of homologous compounds of curcuminoid isolated from temulawak (Curcuma xanthorriza roxb.) plant. Rasayan J. Chem. 12: 7-13.

10. Zuzarte-Luis V, Mota MM, Vigário AM (2014) Malaria infections: What and how can mice teach us. J. Immunol. Methods 410: 113-122.

11. Ihwah A, Deoranto P, Wijana S, Dewi IA (2018) Comparative study between Federer and Gomez method for number of replication in complete randomized design using simulation: Study of Areca Palm (Areca catechu) as organic waste for producing handicraft paper. IOP Conf. Ser. Earth Environ. Sci. 131: (1-7). 
12. Widyawaruyanti A, Khasanah U, Tumewu L, Ilmi H, Hafid AF, Tantular IS (2015) Antimalarial activity and cytotoxicity study of ethanol extract and fraction from Alectryon serratus leaves. Int. J. Pharm. Pharm. Sci. 7: 250-253.

13. Reddy RC, Vatsala PG, Keshamouni VG, Padmanaban G, Rangarajan PN (2005) Curcumin for malaria therapy. Biochem. Biophys. Res. Commun 326: 472-474.

14. Adetutu A, Olorunnisola OS, Owoade AO, Adegbola P (2016) Inhibition of In Vivo Growth of Plasmodium berghei by Launaea taraxacifolia and Amaranthus viridis in Mice. Malar. Res. Treat. 2016: 1-9.

15. Somsak V, Polwiang N, Chachiyo, S (2016) In Vivo Antimalarial Activity of Annona muricata Leaf Extract in Mice Infected with Plasmodium berghei. J. Pathog. 2016: 1-5.

16. Minggarwati TS (2017) Uji Aktivitas Antikanker dan Identifikasi Senyawa Aktif Dari Fraksi Umbi Bawang Sabrang (Eleutherine palmifolia(L.) Merr.) Terhadap Sel Kanker serviks HeLa.

17. He Y, Yue Y, Zheng X, Zhang K, Chen S, Du Z (2015) Curcumin, inflammation, and chronic diseases: How are they linked? Molecules 20: 9183-9213.
18. Rohlan K, Choudhary S, Kumar V, Shringi N (2018) Embedding Techniques in Tissue Histological Process. In Latest Trends in Zoology and Entomology Sciences Volume 1; Ganguly, S., Rohlan, K., Eds.; AkiNik Publications, Rohini, Delhi, India: New Delhi: 38-42.

19. Viriyavejakul P, Khachonsaksumet V, Punsawad C (2014) Liver changes in severe Plasmodium falciparum malaria : histopathology, apoptosis and nuclear factor kappa B expression Liver changes in severe Plasmodium falciparum malaria : histopathology, apoptosis and nuclear factor kappa B expression. Malar. J. 13: 1-9.

20. Pisciotta JM, Scholl PF, Shuman JL, Shualev V, Sullivan DJ (2017) Quantitative characterization of hemozoin in Plasmodium berghei and vivax. Int. J. Parasitol. Drugs Drug Resist. 7: 110-119.

21. Abu Lafi S, Akkawi M, Abu Remeleh Q, Qutob M, Lutgen $P$ (2019) Curcumin, a natural isolate from Curcuma longa (turmeric) with high $\beta$-hematin inhibitory potential. Pharm. Pharmacol. Int. J. 7: 22-26.

22. Panche AN, Diwan AD, Chandra SR (2016) Flavonoids: An overview. J. Nutr. Sci. 5: 1-8. 